\title{
Nest Success and Duckling Survival of Greater Scaup, Aythya marila, at Grassy Island, New Brunswick
}

\author{
Nicole M. Tatman ${ }^{1}$, Jon T. McRoberts ${ }^{1}$, W. Andrew Smith ${ }^{2,3}$, Warren B. Ballard ${ }^{1}$, F. Patrick \\ KeHOE $^{4}$ and Timothy G. Dilworth ${ }^{2}$ \\ ${ }^{1}$ Department of Natural Resources Management, Texas Tech University, Lubbock, Texas 79409 USA \\ ${ }^{2}$ Department of Biology, University of New Brunswick, Bag Service \# 45111, Fredericton, New Brunswick E3B 6E1 Canada \\ ${ }^{3}$ Current address: 3 ASG Engineer Branch Building B18 Canadian Forces Base Gagetown, P.O. Box 17000 Station Forces, \\ Oromocto, New Brunswick E2V 4J5 Canada \\ ${ }^{4}$ Ducks Unlimited Canada, $16064^{\text {th }}$ Avenue, P.O. Box 4465, Regina, Saskatchewan S4P 3W7 Canada \\ ${ }^{2}$ Correspondence e-mail: Andy.Smith@forces.gc.ca
}

Tatman, Nicole M., Jon T. McRoberts, W. Andrew Smith, Warren B. Ballard, F. Patrick Kehoe, and Timothy G. Dilworth. 2009. Nest success and duckling survival of Greater Scaup, Aythya marila, at Grassy Island, New Brunswick. Canadian Field-Naturalist 123(4): 323-328.

Nesting biology and duckling survival of Greater Scaup (Aythya marila) at Grassy Island on the Saint John River in southern New Brunswick were compared between 1995 and 1996. Grassy Island in New Brunswick is an area that is notably removed from other scaup breeding areas, being located farther south from main breeding areas in North America. The Mayfield estimates of nest success were $61 \%$ and $21 \%$ in 1995 and 1996, respectively. Mean daily survival rates were 0.99 in 1995 and 0.96 in 1996 and were significantly different $(\mathrm{t}=4.86, P<0.001)$. Duckling survival was estimated to range from 38 to $54 \%$ in 1995, and was $8 \%$ in 1996. The lower breeding success in 1996 may have been due to factors associated with decreased temperatures and increased precipitation, but the fact that the breeding location is atypical to other Greater Scaup breeding areas should not be overlooked.

Key Words: Greater Scaup, Aythya marila, nest success, duckling survival, New Brunswick.

Duckling mortality is usually greatest in the first one to two weeks post-hatch and can influence duckling recruitment. Variation in nesting success of Mallards (Anas platyrhynchos) influenced changes in annual population size more than any other criterion (Hoekman et al. 2002). Additionally, Flint et al. (2006) found that scaup productivity explained more variation in population trends than adult survival. Therefore, relatively small changes in nesting success have the ability to result in large decreases in recruitment. Identifying reasons behind failed nest attempts throughout the range of Greater Scaup (Aythya marila) is important, particularly in isolated breeding areas that are not well studied (Austin et al. 2000).

Duckling mortality has been associated with poor weather (Blums et al. 2002; Jonsson et al. 2009). Ducklings of most species have poor thermoregulatory capabilities and are vulnerable to cold and wet situations. Weather may indirectly increase mortality rates of ducklings by reducing their ability to feed (Hilden 1964) or by altering their behavior, possibly resulting in an increased risk of predation (Mendenhall and Milne 1985). During our study in 1996, the late incubation, hatching and early brood rearing periods (July through early August) of Greater Scaup nesting at Grassy Island, New Brunswick were significantly cooler and wetter than 1995 (Smith 1999). Precipitation in 1996 was more than double the observed value in 1995 (National Climate Data and Information Archive 2008). Concurrent with the higher precipitation (Figure 1) were rising water levels (approximately $1 \mathrm{~m}$ higher in 1996) which flooded nests and altered brood rearing habitat (Smith 1999). We examine the nesting biology and duckling survival of Greater Scaup in this farremoved southernmost breeding area (McAlpine et al. 1988) and discuss how environmental attributes may have influenced their nesting success.

\section{Study Area}

The study was conducted on the Saint John River at Oak Point, in southern New Brunswick $\left(45^{\circ} 31^{\prime} \mathrm{N}\right.$, $\left.66^{\circ} 05^{\prime} \mathrm{W}\right)$. The surrounding area is deltaic in character containing several islands, coves, and extensive beds of aquatic vegetation (Choate 1973*). River levels fluctuate over $2.5 \mathrm{~m}$ seasonally and fluctuations of $6 \mathrm{~m}$ have been recorded (Choate 1973*). Nesting data were collected from Grassy Island $\left(45^{\circ} 31^{\prime} \mathrm{N}\right.$, $66^{\circ} 04^{\prime} \mathrm{W}$ ), a low-lying 32 ha island located $0.7 \mathrm{~km}$ offshore from Oak Point. Island vegetation was dominated by grasses (Calamagrostis spp., Phalaris spp.), forbs (predominantly Lythrum salicaria), sedges (Carex and Cyperus spp.), a few small stands of shrubs (Cornus and Alnus spp.) and trees (Fraxinus and Acer spp.). The island is submerged annually during spring flooding (A. Smith, personal observation). Common Terns (Sterna hirundo), Ring-billed Gulls (Larus delawarensis) and Great Black-backed Gulls (L. marinus) also nest on the island. This location is removed and farther south of the larger breeding area for Greater Scaup. 


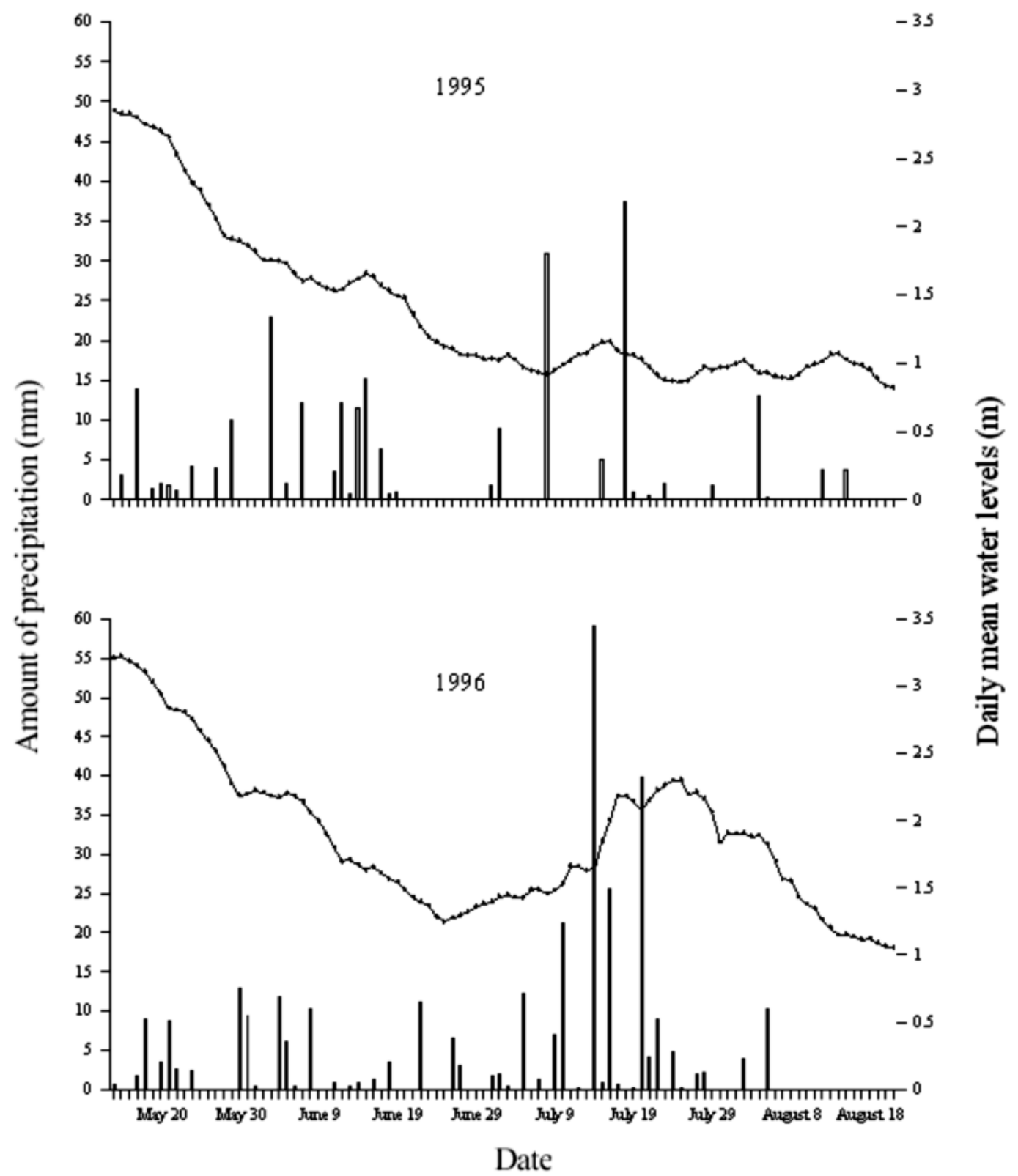

FIGURE 1: Precipitation (bars) and water levels (lines) at Oak Point, New Brunswick during the 1995 and 1996 Greater Scaup breeding seasons.

\section{Methods}

Scaup nest sites were found by systematic searches conducted by 5 to 10 people during mid-morning (Gloutney et al. 1993), on four dates in 1995 (15, 22, 27 June and 6 July), three dates in 1996 (18, 25 June and 3 July) and opportunistically when conducting other field work. Nests were mapped and relative nest elevation was estimated. All nests were monitored to determine their fate. When females flushed from nests, researchers covered the eggs with down and other nest material, and placed a string on top of the eggs. If on a subsequent visit the string had not been moved (i.e., indicating that the female had not returned to the nest), it was assumed that the bird had abandoned the nest (Klett et al. 1986). Nest initiation was estimated by backdating from hatch dates or an age estimated by candling; or if found during laying, by counting the number of eggs (assuming one egg laid per day; Weller 
TABLE 1. Fate of Greater Scaup nests found on Grassy Island, New Brunswick in 1995 and 1996.

\begin{tabular}{|c|c|c|c|c|}
\hline \multirow[b]{2}{*}{ Fate } & \multicolumn{2}{|c|}{1995} & \multicolumn{2}{|c|}{1996} \\
\hline & $\mathrm{n}$ & $\%$ & $\mathrm{n}$ & $\%$ \\
\hline Abandoned & 22 & 19.3 & 41 & 36 \\
\hline Hatched & 61 & 53.5 & 32 & 28.1 \\
\hline Depredated & 4 & 3.5 & 17 & 14.9 \\
\hline Flooded & 0 & 0 & 7 & 6.1 \\
\hline Abandoned due to researchers ${ }^{\mathrm{a}}$ & 3 & 2.6 & 2 & 1.8 \\
\hline $\begin{array}{l}\text { Abandoned or perished due to trapping, } \\
\text { marking or radio tagging }\end{array}$ & 14 & 12.3 & 13 & 11.4 \\
\hline Unknown ${ }^{\mathrm{c}}$ & 10 & 8.8 & 2 & 1.8 \\
\hline
\end{tabular}

${ }^{a}$ Nests were abandoned during laying or early incubation, most likely due to nest checking activities.

${ }^{\mathrm{b}}$ During 1995, 14 nests were abandoned due to trapping and nasal marking. During 1996, 9 nests were abandoned due to trapping, marking and radio-tagging activities, and 4 hens died during radio-implant operations.

${ }^{c}$ Nests were lost so their fate was unknown.

1956). Incubation was assumed to last 27 days (Johnsgard 1975; Bellrose 1980). Clutch size was defined as the maximum number of eggs observed in a nest. We considered nests with $>12$ eggs as dump or community nests, and these were excluded from clutch size analysis (Weller et al. 1969). Eggs that did not hatch, and were not thought to be from parasitic laying, were counted as unhatched. No distinction was made between infertile and unviable eggs.

Nest success was estimated using the modified Mayfield method, and daily survival rates were compared using a t-test (Mayfield 1961, 1975; Johnson 1979; Klett et al. 1986). Dates of nest abandonment were rarely known so they were estimated by adding the number of days of probable exposure as determined by the modified Mayfield method, to the last date the nest was observed to be viable (Klett et al. 1986). Probable exposure equaled half of the interval between the last date the nest was viable, and the date when nest fate was determined or the estimated hatch date, whichever was less. If the interval was $>14$ days, it was multiplied by 0.4 instead of 0.5 (Johnson 1979). Nest age at abandonment was determined by subtracting the date of nest initiation from the date of abandonment. Nests that were destroyed due to flooding were considered separately from abandoned nests.

The frequencies of hatching, abandonment and predation were compared between years using a chi-square test of independence. Between-year differences in variables were tested with Wilcoxon rank-sum test. Tests of skewness were used to compare the distribution of nest- initiation dates, hatch dates and abandonment dates, and nest age at abandonment between years (Snedecor and Cochran 1967). Nests of unknown fate or failed due to researcher activities were not included in analyses of abandoned nests.

In 1995, nine brood surveys were conducted by boat between 13 and 31 August. In 1996, 6 brood surveys were conducted by boat between 13 and 21 August. All surveys were conducted during daylight hours. A regular route was followed and ducklings counted from vantage points at known brood-rearing areas and opportunistically. Brood surveys were also conducted from airplane during mid-morning on $28 \mathrm{Au}-$ gust 1995 and 16 August 1996. When a brood was observed, it was circled until species, and number of adults and young, could be verified by two observers.

During 1996, seven nests were found on Rush $\left(45^{\circ} 30^{\prime} \mathrm{N}, 66^{\circ} 05^{\prime} \mathrm{W}\right)$ and $\operatorname{Hog}\left(45^{\circ} 33^{\prime} \mathrm{N}, 66^{\circ} 01^{\prime} \mathrm{W}\right)$ Islands located near Grassy Island. Two of the seven nests hatched a total of 12 eggs. Those islands were not searched in 1995. To account for duckling production from those islands in 1995, the number of nests found in 1996 (7) was multiplied by median clutch size (9), and percentage of eggs hatched (47\%) from nests on Grassy Island in 1995 for an estimated 30 hatched eggs. The two islands were searched only once each so it was likely that some nests were missed. Therefore, these estimates should be considered the minimum production of ducklings.

The ratio of ducklings observed in mid to late August to eggs hatched was used as a rough estimate of duckling survival. A chi-square test was used to compare survival between the two years of the study.

\section{Results}

A total of 114 nests were found on Grassy Island in both 1995 and 1996. The Mayfield estimate of nest success was $61 \%$ in 1995 and $21 \%$ in 1996. Mean daily survival rates of 0.99 ( $\mathrm{SE}= \pm 0.003)$ in 1995 and $0.96(\mathrm{SE}= \pm 0.005)$ in 1996 were significantly different ( $\mathrm{t}=4.86, P<0.001)$. Fewer nests hatched, and more were abandoned and preyed upon in 1996 than expected when compared to $1995\left(X^{2}=22.78, P<0.001\right.$; Table 1). The date of abandonment was positively skewed in $1995(P<0.05)$, but was negatively skewed in $1996(P<0.05$; Figure 2$)$.

In 1995, 426 eggs hatched on Grassy Island. An estimated minimum hatch of 30 eggs on other islands resulted in a minimum total hatch of 456 eggs. Number of scaup ducklings observed during boat surveys ranged from 70 to 179 . A survey conducted on 31 
TABLE 2. Some statistics from greater scaup nests found on Grassy Island, New Brunswick in 1995 and 1996.

\begin{tabular}{lccccccc}
\hline \hline & \multicolumn{3}{c}{1995} & & & \multicolumn{2}{c}{1996} \\
\cline { 2 - 4 } Characteristic $^{\mathrm{a}}$ & $\mathrm{N}$ & Mean & $\mathrm{SE}$ & & $\mathrm{n}$ & Mean & SE \\
\hline Fall clutch size & 99 & 8.74 & 0.15 & 101 & 8.83 & 0.17 \\
Unhatched eggs/hatched clutch & 60 & 1.43 & 0.20 & 32 & 1.69 & 0.34 \\
Relative nest elevation (m) & 104 & 0.86 & 0.02 & 114 & 0.89 & 0.02 \\
Date of nest initiation* & 109 & June 14 & 0.78 & 106 & June 16 & 0.81 \\
Date of nest abandonment & 22 & July 8 & 2.64 & 39 & July 11 & 2.45 \\
Age at nest abandonment & 21 & 20.32 & 1.95 & 36 & 24.46 & 1.34 \\
Hatch date & 60 & July 19 & 0.97 & 32 & July 19 & 1.18 \\
\hline \hline
\end{tabular}

${ }^{\text {a }}$ Differences between years were not significant using a Wilcoxon rank sum test unless indicated.

$* \mathrm{p}<0.05$

TABLE 3. Weather conditions in southern New Brunswick during the Greater Scaup breeding season 1995 and 1996.

\begin{tabular}{|c|c|c|c|c|c|}
\hline & \multicolumn{2}{|c|}{1995} & \multicolumn{2}{|c|}{1996} & \multirow[b]{2}{*}{ Test } \\
\hline & Mean & SE & Mean & $\overline{\mathrm{SE}}$ & \\
\hline \multicolumn{6}{|l|}{ Season $(n=99,96)^{a}$} \\
\hline Mean daily temperature $\left({ }^{\circ} \mathrm{C}\right)$ & 16.56 & 0.38 & 15.65 & 0.35 & $z=-1.91$ \\
\hline Mean daily precipitation (mm) & 2.43 & 0.61 & 3.25 & 0.85 & $\mathrm{z}=1.09$ \\
\hline Mean daily wind speed $(\mathrm{km} / \mathrm{hr})$ & 9.65 & 0.39 & 11.60 & 0.55 & $\mathrm{z}=2.43^{*}$ \\
\hline Mean daily water level (m) & 1.39 & 0.06 & 1.82 & 0.10 & $\mathrm{z}=6.21 * * *$ \\
\hline \multicolumn{6}{|l|}{ Prelaying $(n=14,14)$} \\
\hline Mean daily temperature $\left({ }^{\circ} \mathrm{C}\right)$ & 10.61 & 0.58 & 10.64 & 0.90 & $t=-0.03$ \\
\hline Mean daily precipitation (mm) & 2.25 & 0.97 & 3.44 & 1.21 & $\mathrm{z}=-0.10$ \\
\hline Mean daily wind speed $(\mathrm{km} / \mathrm{hr})$ & 9.88 & 1.22 & 13.86 & 1.75 & $\mathrm{t}=-1.87$ \\
\hline Mean daily water level (m) & 2.56 & 0.07 & 2.65 & 0.08 & $\mathrm{t}=-0.86$ \\
\hline \multicolumn{6}{|l|}{ Laying $(\mathrm{n}=37,39)$} \\
\hline Mean daily temperature $\left({ }^{\circ} \mathrm{C}\right)$ & 15.73 & 0.47 & 15.03 & 0.39 & $\mathrm{t}=1.15$ \\
\hline Mean daily precipitation (mm) & 2.96 & 0.91 & 2.07 & 0.59 & $z=-0.24$ \\
\hline Mean daily wind speed $(\mathrm{km} / \mathrm{hr})$ & 10.03 & 0.69 & 12.33 & 0.73 & $\mathrm{t}=-2.29 *$ \\
\hline Mean daily water level (m) & 1.47 & 0.05 & 1.64 & 0.05 & $z=-1.34$ \\
\hline \multicolumn{6}{|l|}{ Early Incubation $(\mathrm{n}=29,25)$} \\
\hline Mean daily temperature $\left({ }^{\circ} \mathrm{C}\right)$ & 16.81 & 0.49 & 14.79 & 0.52 & $\mathrm{t}=2.85^{* *}$ \\
\hline Mean daily precipitation (mm) & 2.14 & 0.80 & 1.77 & 0.67 & $z=0.65$ \\
\hline Mean daily wind speed $(\mathrm{km} / \mathrm{hr})$ & 9.93 & 0.79 & 12.45 & 1.00 & $\mathrm{t}=-1.99$ \\
\hline Mean daily water level (m) & 1.28 & 0.05 & 1.45 & 0.03 & $\mathrm{z}=2.13^{*}$ \\
\hline \multicolumn{6}{|l|}{ Late Incubation $(\mathrm{n}=29,25)$} \\
\hline Mean daily temperature $\left({ }^{\circ} \mathrm{C}\right)$ & 18.94 & 0.44 & 17.37 & 0.34 & $\mathrm{t}=2.78^{* *}$ \\
\hline Mean daily precipitation (mm) & 3.17 & 1.67 & 7.04 & 2.92 & $\mathrm{z}=1.98^{*}$ \\
\hline Mean daily wind speed $(\mathrm{km} / \mathrm{hr})$ & 9.25 & 0.60 & 12.18 & 1.03 & $\mathrm{z}=2.19^{*}$ \\
\hline Mean daily water level (m) & 0.98 & 0.02 & 1.96 & 0.07 & $\mathrm{z}=6.28 * * *$ \\
\hline \multicolumn{6}{|l|}{ Hatching $(\mathrm{n}=31,26)$} \\
\hline Mean daily temperature $\left({ }^{\circ} \mathrm{C}\right)$ & 18.83 & 0.41 & 17.28 & 0.34 & $\mathrm{t}=2.82^{* *}$ \\
\hline Mean daily precipitation (mm) & 2.96 & 1.57 & 6.92 & 2.81 & $\mathrm{z}=2.30^{*}$ \\
\hline Mean daily wind speed $(\mathrm{km} / \mathrm{hr})$ & 9.55 & 0.60 & 11.98 & 1.01 & $\mathrm{z}=1.73$ \\
\hline Mean daily water level (m) & 0.98 & 0.01 & 1.96 & 0.05 & $\mathrm{z}=6.45^{* * *}$ \\
\hline \multicolumn{6}{|l|}{ Early Brood Rearing $(\mathrm{n}=23,23)$} \\
\hline Mean daily temperature $\left({ }^{\circ} \mathrm{C}\right)$ & 18.90 & 0.46 & 17.37 & 0.37 & $\mathrm{t}=2.59^{*}$ \\
\hline Mean daily precipitation (mm) & 3.33 & 2.05 & 7.65 & 3.15 & $\mathrm{z}=-2.37 *$ \\
\hline Mean daily wind speed $(\mathrm{km} / \mathrm{hr})$ & 9.10 & 0.74 & 12.68 & 1.06 & $z=-2.44^{*}$ \\
\hline Mean daily water level (m) & 0.99 & 0.01 & 1.97 & 0.07 & $\mathrm{z}=-5.80 * * *$ \\
\hline \multicolumn{6}{|l|}{ Late Brood Rearing $(\mathrm{n}=23,22)$} \\
\hline Mean daily temperature $\left({ }^{\circ} \mathrm{C}\right)$ & 18.85 & 0.53 & 18.17 & 0.46 & $\mathrm{t}=0.96$ \\
\hline Mean daily precipitation (mm) & 0.98 & 0.59 & 0.64 & 0.49 & $z=-1.03$ \\
\hline Mean daily wind speed $(\mathrm{km} / \mathrm{hr})$ & 9.67 & 0.72 & 7.74 & 0.88 & $z=-1.98^{*}$ \\
\hline Mean daily water level (m) & 0.96 & 0.01 & 1.44 & 0.07 & $\mathrm{z}=5.64 * * *$ \\
\hline
\end{tabular}

${ }^{a} \mathrm{n}$ is the number of days in the period 1995 and 1996 respectively.

$* \mathrm{p}<0.05, * * \mathrm{p}<0.01, * * * \mathrm{p}<0.0001$ 
August recorded 175 ducklings. A total of 244 ducklings was counted on 28 August 28 in an airplane survey. Duckling survival (based on 456 eggs hatched) ranged from an estimated $38.4 \%$ (assuming 175 ducklings survived) to $53.5 \%$ (assuming 244 ducklings survived).

In 1996, 226 eggs hatched on Grassy Island plus a minimum of 12 more on other islands for a total of 238. Number of scaup ducklings observed during boat surveys ranged from 2 to 18 . Two broods totaling 16 ducklings were observed during an airplane survey on 16 August. Based on their numbers and locations, duckling production in 1996 was estimated to be approximately 20 individuals, representing a survival rate of $8.4 \%$. Compared to 1995, far fewer ducklings survived to fledging than expected in $1996\left(X^{2}=42.70\right.$, $P<0.001)$. The late incubation, hatching and early brood-rearing stages (July through early August) during 1996 were significantly cooler and wetter (Figure 1; Table 3) than 1995 (Smith 1999).

\section{Discussion}

We present information on Greater Scaup nest success and duckling survival at their southernmost breeding location. Duckling survival was lower in 1996 than 1995. The difference in nesting success between 1995 and 1996 was possibly due to cooler temperatures and high precipitation causing high water levels during late incubation and hatching periods in 1996. Seven nests were destroyed by flooding in 1996, and several were observed that had material added to raise them (i.e., cone nests; Hilden 1964). Almost twice as many nests were abandoned in 1996 compared to 1995 . In 1996, females may have abandoned their nests late in incubation out of necessity in order to devote more time to feeding and self-maintenance (Korschgen 1977; Ankney and MacInnes 1978; Gloutney and Clark 1991). Other studies have found similar results when studying other duck species during poor weather conditions (Bengtson 1972; Makepeace and Patterson 1980; Mendenhall and Milne 1985; Walker et al. 2005).

The increased mortality of ducklings in 1996 may have been due to decreased foraging opportunities caused by inclement weather. During the first few days of life, diving ducklings generally feed on the surface (Bengtson 1971, 1972; Sugden 1973; Hill and Ellis 1984). Invertebrate production and emergence may have been reduced during 1996 (Sjoberg and Danell 1982; Anderson and Wallace 1984). Furthermore, flooding delayed the growth of emergent bulrush (Scirpus spp.) and sedge stands which are used for brood-rearing (A. Smith personal observation). These areas would normally provide shelter and hold invertebrate food during bad weather (Hilden 1964, Sjoberg and Danell 1982). Also, the seeds of sedges can be an important food to Greater Scaup ducklings (Bengtson 1971).

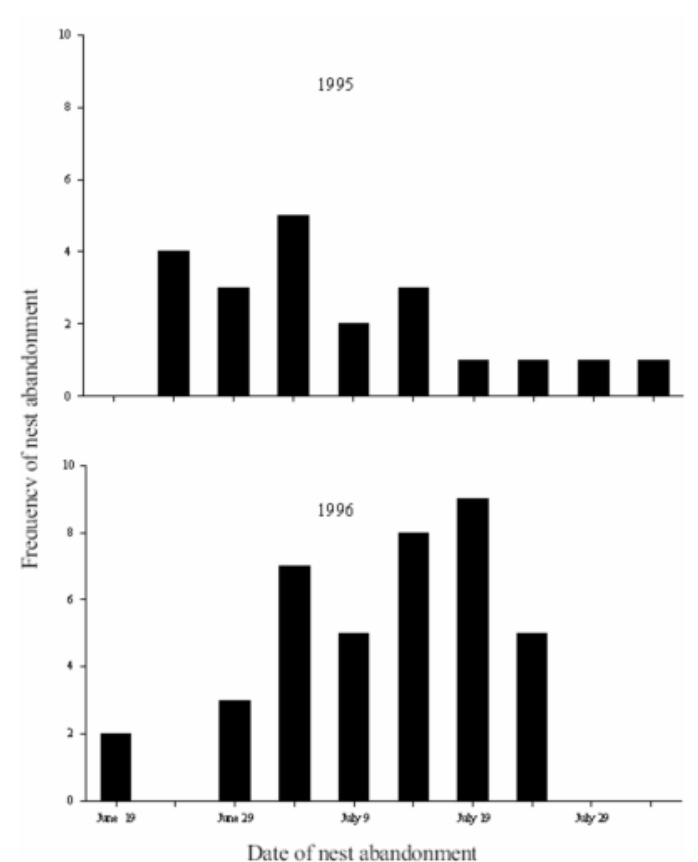

FIGURE 2. Estimated date of nest abandonment by Greater Scaup nesting at Grassy Island, New Brunswick, in 1996 and 1996 (grouped into 5 day periods).

The low temperatures, high precipitation, and high water levels on the Saint John River in 1996 negatively influenced the breeding success of additional bird species. Breeding activity of Yellow Rails (Coturnicops noveboracensis) at the Grand Lake Meadows upriver from our study site, ceased after their habitat was flooded (Kehoe et al. 2000). Yellow Warblers (Dendroica petechia) suffered decreased nesting success compared to 1995 at several sites in southern New Brunswick (S. Makepeace, New Brunswick Department of Natural Resources and Energy, Fredericton, New Brunswick, unpublished data).

Many species distribution boundaries are dictated by temperature and precipitation. As this study site is the southernmost breeding area for Greater Scaup in North America (McAlpine et al. 1988), determining whether climate change is shifting these boundaries could be an area of future research.

\section{Acknowledgments}

We thank the students and staff of the University of New Brunswick, and staff of the New Brunswick Department of Natural Resources and Energy who assisted with data collection. P. Collins assisted with GPS and surveying applications. We gratefully acknowledge the financial support of the New Brunswick Department of Natural Resources and Energy, the University of New Brunswick, and the New Brunswick Cooperative Fish and Wildlife Research Unit. 
Documents Cited (marked $*$ in text)

Choate, J. S. 1973. Water use for wildlife in the Saint John River Basin. Report \#S8. Saint John River Basin Board, Fredericton, Summary Report S8, New Brunswick. 65 pages.

\section{Literature Cited}

Anderson, N. H., and J. B. Wallace. 1984. Habitat, life history and behavioral adaptations of aquatic insects. Pages 38-58 in An introduction to the aquatic insects of North America. Edited by R. W. Merrit and K. W. Cummins. Kendall/Hunt Publishing Co., Dubuque, Iowa.

Ankney, C. D., and C. D. MacInnes. 1978. Nutrient reserves and reproductive performance of female Lesser Snow Geese. Auk 95: 459-471.

Austin, J. E., A. D. Afton, M. G. Anderson, R. G. Clark, C. M. Custer, J. S. Lawrence, J. B. Pollard, and J. K. Ringelman. 2000. Declining scaup populations: issues hypotheses, and research needs. Wildlife Society Bulletin 28: 254-263.

Bellrose, F. C. 1980. Ducks, geese and swans of North America. $3^{\text {rd }}$ edition. Stackpole Books. Harrisburg, Pennsylvania. 568 pages.

Bengtson, S.-A. 1971. Food and feeding of diving ducks breeding at Lake Myvatn, Iceland. Ornis Fennica 48: 7792.

Bengtson, S.-A. 1972. Reproduction and fluctuations in the size of duck populations at Lake Myvatn, Iceland. Oikos 23: 35-58.

Blums, P., R. G. Clark, and A. Mednis. 2002. Patterns of reproductive effort and success in birds: path analyses of long-term data from European ducks. Journal of Animal Ecology 71: 280-295.

Flint, P. L., J. B. Grand, T. F. Fondell, and J. A. Morse. 2006. Population dynamics of greater scaup breeding on the Yukon-Kuskokwim Delta, Alaska. Wildlife Monographs 162: 1-22.

Gloutney, M. L., and R. G. Clark. 1991. The significance of body mass to female dabbling ducks during late incubation. Condor 93: 811-816.

Gloutney, M. L., R. G. Clark, A. D. Afton, and G. F. Huff. 1993. Timing of nest searches for upland nesting waterfowl. Journal of Wildlife Management 57: 597-601.

Hilden, O. 1964. Ecology of duck populations in the island group of Valassaaret, Gulf of Bothnia. Annales Zoologici Fennici 1: 153-279.

Hill, D. A., and N. Ellis. 1984. Survival and age related changes in the foraging behaviour and time budget of Tufted Ducklings, Aythya fuligula. Ibis 126: 544-550.

Hoekman, S. T., L. S. Mills, D. W. Howerter, J. H. Devries, and I. J. Ball. 2002. Sensitivity analyses of the life cycle of mid-continent mallards. Journal of Wildlife Management 66: 883-900.

Johnsgard, P. A. 1975. Waterfowl of North America. Indiana University Press, Bloomington, Indiana. 575 pages.

Johnson, D. H. 1979. Estimating nest success: the Mayfield method and an alternative. Auk 96: 651-661.
Jonsson, J. E., A. Gardarsson, J. A. Gill, A. Petersen, and T. G. Gunnarsson. 2009. Seasonal weather effects on the common eider, a subarctic capital breeder, in Iceland over 55 years. Climate Research 38: 237-248.

Kehoe, F. P., L. A. Swanson, G. J. Forbes, S. Bowes, and P. A. Pearce. 2000. New yellow rail (Coturnicops noveboracencis) site in Atlantic Canada. Canadian Field-Naturalist 114: 331-332.

Klett, A. T., H. F. Duebbert, C. A. Faanes, and K. F. Higgins. 1986. Techniques for studying nest success of ducks in upland habitats in the prairie pothole region. U. S. Department of the Interior, Fish and Wildlife Service, Resource Publication Number 158. Washington, D.C. 24 pages.

Korschgen, C. E. 1977. Breeding stress of female eiders in Maine. Journal of Wildlife.

Makepeace, M., and L. J. Patterson. 1980. Duckling mortality in the Shelduck, in relation to density, aggressive interaction and weather. Wildfowl 31: 57-72.

Mayfield, H. 1961. Nesting success calculated from exposure. Wilson Bulletin 73: 255-261.

McAlpine, D. F., S. Makepeace, S., and M. Phinney. 1988. Breeding records of greater scaup (Aythya marila) in New Brunswick. Canadian Field-Naturalist 102:718-719.

Mendenhall, V. M., and H. Milne. 1985. Factors affecting duckling survival of Eiders Somateria mollissima in northeast Scotland. Ibis 127: 148-158.

National Climate Data and Information Archive. 2008. Website: [http://www.climate.weatheroffice.ec.gc.ca/Wel come_e.html]

Sjoberg, K., and K. Danell. 1982. Feeding activity of ducks in relation to diel emergence of chironomids. Canadian Journal of Zoology 60: 1383-1416.

Smith, W. A. 1999. Nest site selection and nest fate of Greater Scaup on Grassy Island, New Brunswick: the influence of habitat, larids and weather. M Sc. thesis, University of New Brunswick, Fredericton, New Brunswick. 134 pages.

Snedecor, G. W., and W. G. Cochran. 1967. Statistical methods. Iowa State University Press, Ames, Iowa. 593 pages.

Sugden, L. G. 1973. Feeding ecology of Pintail, Gadwall, American Widgeon, and Lesser Scaup ducklings. Canandian Wildlife Service Report Series Number 24. Information Canada, Ottawa, Ontario. 43 pages.

Walker, J., M. S. Lindberg, M. C. MacCluskie, M. J. Petrula and J. S. Sedinger. 2005. Nest survival of Scaup and other ducks in the boreal forest of Alaska. Journal of Wildlife Management 69: 582-591.

Weller, M. W. 1956. A simple field candler for waterfowl eggs. Journal of Wildlife Management 20: 111-113.

Weller, M. W., D. L. Trauger, and G. L. Krapu. 1969. Breeding birds of the West Mirage Islands, Great Slave Lake, N. W. T. Canadian Field-Naturalist 83: 344-360.

Received 2 June 2000

Revised 25 February 2010

Accepted 25 May 2010 